\title{
COMPARISON OF THE PERFORMANCE VALUES OF THE U-16 DEVELOPMENT LEAGUE FOOTBALL PLAYERS IN THE COMPETITION PERIOD
}

\author{
Mahmut Kurtay ${ }^{1}$, \\ Zafer Bilgin²i, \\ Murat Taş² \\ ${ }^{1}$ Department of Physical Education and Sport Education, \\ Institute of Health Sciences Manisa Celal Bayar University, \\ Manisa, Turkey \\ ${ }^{2}$ Department of Sports Health Sciences, \\ Coaching Education Department, Faculty of Sports Science, \\ Manisa Celal Bayar University, \\ Manisa, Turkey
}

\begin{abstract}
:
This study aims to compare the performance values of U-16 development league football players. The research was carried out according to the experimental research model. A total of 25 football players of a super league football team (age: 16, height: 170,36 $\pm 7,31 \mathrm{~cm}$, weight: $56,89 \pm 8,88 \mathrm{~kg}$ ), all competing in the U-16 elite development league, participated voluntarily. The players wear Polar watches on the grass football field; Yo-Yo Intermittent Recovery Level 1 test was applied and aerobic endurance levels, maximal heart rate, and heart rate recovery times were measured. Tests and measurements were applied 1 week before the start of the league. After the first test, the competition period general training program was applied for 9 weeks, 4 days a week, and after that, the same tests and measurements were carried out again. After a 9-week competition training program, there were statistically significant differences in aerobic endurance levels and heart rate recovery times at the 1 st minute $(\mathrm{p}<0.01)$, no statistically significant differences were found in maximal heart rate and heart rate recovery times at the 2nd minute ( $p>0.01$ ). In conclusion, it can be said that the 9-week training program applied during the competition period is effective on the aerobic endurance level and heart rate recovery time in the 1 st minute.
\end{abstract}

Keywords: development league, aerobic endurance, maximum heart rate, recovery, heart rate recovery

${ }^{i}$ Correspondence: email zaff23@gmail.com 


\section{Introduction}

Development leagues constitute the basic structure of our country's football. In football, the development leagues are the infrastructure of all teams from the amateur league to the super league. When we look at the success of Turkish teams, football players, and the national team in European and world tournaments, we see how far we are behind compared to other countries. So, to make the world talk about Turkish football and football players in the future, we think that the group that needs to be studied the most in terms of psychological, sociological, and performance science, is the development leagues. Football is a sport that includes aerobic and anaerobic energy systems (Açıkada, et al., 1999). The players' ability to benefit from these energy systems at the highest level is ensured by the development of physical and motoric performance (Taşkın, et al., 2015). In all sports branches, both the player and the coach need to use the correct data and the correct training program by applying scientific methods for performance enhancement (Kizilet, et al., 2010). Recovery also comes forth in branches where sudden performance changes occur during the match, such as football. The short recovery time contributes to the athlete's performance at the highest level for longer. One of the most important factors affecting this is the heart rate. Heart rate variability (HRV) may differ according to age and gender. It is also known that the athlete shows variability in situations such as hungry, full, standing, etc. Studies show that regular exercise increases HRV. Parasympathetic and sympathetic nerves affect heart rate. While parasympathetic has a decelerating effect, sympathetic increases the heart rate (Ateş, 2014; Berntson et al., 1997; Shaffer and Ginsberg, 2017) Heart rate analysis during exercise and recovery informs us of cardiac autonomic recovery (Javorka et al., 2002). Heart rate parallels this autonomic recovery, that is, heart rate also shows a great decrease (Imai et al., 1994). After exercise, a gradual slowdown in metabolic activities and a decrease in heart rate begin (Peçanha et al., 2016). Conditions such as training, age, gender, nutrition, genetic structure, etc. are the most important factors affecting the heart rate. Due to these factors, the number of heartbeats differs according to the individuals (Tamer, 2000). By monitoring the heart rate, the fatigue levels of the athletes can be controlled and unwanted injuries can be prevented. Also, with the development of the energy system desired, the performance capacity will be increased (Açıkada, 1990).

This study aims to compare the performance values of U-16 development league football players.

\section{Materials and Methods}

The research was carried out according to the experimental research model. Also, the ethical committee report stating that the experimental research conducted is in accordance with the "Declaration of Helsinki on Ethical Principles in Medical Research on Humans" was approved by the Manisa Celal Bayar University Faculty of Medicine Health Sciences Ethics Committee. The participants were informed about the applications 
and tests to be carried out before the study. An informed consent form was obtained from the participants.

A total of 25 football players of a super league football team (age: 16, height: $170,36 \pm 7,31 \mathrm{~cm}$, weight: $56,89 \pm 8,88 \mathrm{~kg}$ ), all competing in the U-16 elite development league, participated voluntarily. The players wore Polar watches and on the grass football field, Yo-Yo Intermittent Recovery Level 1 test was applied. Aerobic endurance levels, maximal heart rate, and heart rate recovery times were measured. Tests and measurements were applied 1 week before the start of the league. After the first test, the competition period general training program was applied for 9 weeks, 4 days a week, and after 9 weeks the same tests and measurements were carried out again.

Anthropometric measurements were taken before the Yo-Yo test. Height was measured in ' $\mathrm{cm}$ ' and barefoot with the heels adjacent to each other (Holtain brand stadiometer with an accuracy of $\pm 1 \mathrm{~mm}$ ). Bodyweight was measured in ' $\mathrm{kg}$ ' when they were barefoot with only shorts and t-shirts and in anatomical posture position. The bodyweight precision of the subjects was $\pm 0.1 \mathrm{~kg}$ (Tefal brand electronic scale).

Yo-Yo Intermittent Recovery Test Level 1 (Yo-Yo IR1) is an endurance test consisting of repetitive runs that start with a running speed of $10 \mathrm{~km} / \mathrm{h}$ between the start, turn, and finish lines in a $2 \times 20 \mathrm{~m}$ area and gradually increase the running speed according to the signal sound coming from the signal device. After every $40 \mathrm{~m}$ run, there is an active recovery area of 10 seconds consisting of $2 \times 5 \mathrm{~m}$ (Stolen et al., 2005). The test consisted of 1 lap at $10 \mathrm{~km} / \mathrm{h}, 1$ lap at $11 \mathrm{~km} / \mathrm{h}, 1$ lap each at 12-13 km/h, 3 laps at 13.5 $\mathrm{km} / \mathrm{h}, 4$ laps at $14 \mathrm{~km} / \mathrm{h}, 8$ laps at $14.5 \mathrm{~km} / \mathrm{h}$ and 8 laps with $0.5 \mathrm{~km} / \mathrm{h}$ increments up to $19.5 \mathrm{~km} / \mathrm{h}$. The test is terminated if the person reaches the point of exhaustion or if he misses two consecutive signals (Krustrup et al., 2003). Tests and measurements were applied 1 week before the start of the league to determine the endurance levels, maximum heart rate (HRmax) values, and heart rate recovery times of the football players. The players participated in the test in groups of 5 under the supervision of 3 football coaches. After the first test, general competition training was applied 4 days a week for 9 weeks, and after 9 weeks the same tests and measurements were carried out again. The \% HRmax values of the subjects were determined by the Yo-Yo Intermittent Recovery Test, and the HR was monitored with a polar watch (RS800CX). At the end of the tests, the highest HR values reached by the subjects were taken into account. The heart rate recovery rate of the players was also measured with the polar watch. A tape was used to measure the areas. As the Yo-Yo IR1 signal transmitter, which is used to determine the distance traveled by the players, HR values, and heart rate recovery; The Yo-Yo IR1 signal program was used with $1 \mathrm{HP}$ brand laptop computer. For the players to hear the incoming signals clearly, 3 loudspeakers were used. An example of the training program is given in Table 1. 


\begin{tabular}{|l|l|}
\hline \multicolumn{2}{l}{ Table 1: Weekly Training Program Example } \\
\hline Days & Program \\
\hline Monday & Rest \\
\hline Tuesday & $\begin{array}{l}\text { Warm up (15min), Aerobic Endurance (30min), Narrow field game (30min), } \\
\text { Cooldown (10min) }\end{array}$ \\
\hline Wednesday & $\begin{array}{l}\text { Warm up (15min), Quick strength training (30min), Game without goal 2x15min, } \\
\text { Cooldown (10min) }\end{array}$ \\
\hline Thursday & Isinma 15dk, 2x30dk Çift kale maç, soğuma 10dk \\
\hline Friday & $\begin{array}{l}\text { Warm up (15min), Sprint training 10x5m, Free kick exercises (20min), } \\
\text { Cooldown (10min) }\end{array}$ \\
\hline Saturday & Rest \\
\hline Sunday & Match \\
\hline
\end{tabular}

The analysis of the data was carried out with the SPSS 25 package program. Frequency and percentage analyzes were used for the descriptive statistics of the research. The paired sample t-test was performed to determine whether Yo-Yo and heart rate tests differed between the measurements. The significance level in the study was determined as $\mathrm{p}<0,01$.

\section{Results}

Weight and height measurements were given in Table 2.

Table 2: Descriptive Statistics

\begin{tabular}{|l|c|c|c|c|c|}
\hline & n & Minimum & Maximum & Mean & Std. Deviation \\
\hline Weight & 25 & 39 & 75 & 56,89 & 8,876 \\
\hline Height & 25 & 153 & 183 & 170,36 & 7,308 \\
\hline
\end{tabular}

As a result of the analysis, it was determined that there was a significant difference in favor of the post-test between the YOYO pre-test average scores (Mean=1516,80, $\mathrm{SD}=478,84)$ and the post-test average scores (Mean=1832,02, $\mathrm{SD}=432,20)(\mathrm{t}=-3,496, \mathrm{p}<0,01)$. It was determined that there was no significant difference between the HRmax pre-test mean scores (Mean=197,88, SD=10,66) and the post-test mean scores (Mean=192,48, $\mathrm{SD}=9,30)$. There was a significant difference in favor of the post test between the 1st minute pulse pre-test mean scores (Mean=165,80, SD=14,74) and the post-test mean scores (Mean=153,28, SD=18,06) (Mean.=165,80, SD=14,74) $(\mathrm{t}=2,783, \mathrm{p}<0,01)$. It was determined that there was no significant difference between the second minute pulse pre-test mean scores (Mean=140,76, SD=13,36) and post-test mean scores (Mean=134,16, SD=13,18) (Table 3). 
Table 3: Yo-Yo IR1 and Heart Rate Results

\begin{tabular}{|c|c|c|c|c|c|c|c|}
\hline & & $\mathrm{n}$ & Mean & Std. Dev. & $\mathbf{t}$ & df & $\mathbf{p}$ \\
\hline \multirow{2}{*}{ YOYO } & Pre-test & 25 & 1516,80 & 478,84 & \multirow{2}{*}{$-3,496$} & \multirow{2}{*}{24} & \multirow{2}{*}{, $002^{*}$} \\
\hline & Post-test & 25 & 1832,02 & 432,20 & & & \\
\hline \multirow{2}{*}{ HRmax } & Pre-test & 25 & 197,88 & 10,66 & \multirow{2}{*}{2,046} & \multirow{2}{*}{24} & \multirow{2}{*}{,052 } \\
\hline & Post-test & 25 & 192,48 & 9,30 & & & \\
\hline \multirow{2}{*}{ 1st min. HR } & Pre-test & 25 & 165,80 & 14,74 & \multirow{2}{*}{2,783} & \multirow{2}{*}{24} & \multirow{2}{*}{, $009^{*}$} \\
\hline & Post-test & 25 & 153,28 & 18,06 & & & \\
\hline \multirow{2}{*}{ 2nd min. HR } & Pre-test & 25 & 140,76 & 13,36 & \multirow{2}{*}{1,639} & \multirow{2}{*}{24} & \multirow{2}{*}{ 114 } \\
\hline & Post-test & 25 & 134,16 & 13,18 & & & \\
\hline
\end{tabular}

HRmax: Maximum heart rate, 1st min. HR:

\section{Discussion}

In this research, the performance values of U-16 development league football players were compared. The effect of the training programs applied to the football players on the aerobic endurance, heart rate, and heart rate recovery rate was examined and the performance of the football players was compared. In this context, when the relevant literature is examined, it is seen that researchers use different training methods to study the endurance levels, heart rates, and heart rate recovery rates of football players.

Javorka et al. (2002) aimed to determine the relationship between the decrease in HR and HRV after exercise. Measurements were taken during different exercises performed by 17 volunteer men $(20.3 \pm 0.2$ years). As a result of the study, no significant relationship was observed between $\mathrm{HR}$ and $\mathrm{HRV}$ in the first minute of the recovery process which is different from the present study. Albinet et al. (2010) in a study they conducted on 24 sedentary women and men (65-78 years old); examined the effect of a 12-week physical exercise program on some parameters of HRV. Similar to the present study they found the 12-week aerobic exercises can increase HRV parameters in sedentary individuals. Ostojic et al. (2011) applied maximal exercises to 32 healthy young football players aged 20-22 years. They examined the recovery levels of football players in 1 minute. As a result of this study, it was revealed that football players with high aerobic capacity responded positively in the short-term recovery period after maximal exercises. In a study by Rostgaard et al. (2008), after a 5-week training period, they found an increase of $31 \%$ in the Yo-Yo-IR1 running distance of elite football players, $17 \%$ increase after 7 weeks of narrow field games, and 22\% increase after speed endurance training. Kurtay et al. (2020) revealed that there was a 34\% increase in aerobic capacity of 18 elite U-14 league football players as a result of 12-week physical performance training, while there was no significant difference in HR values. Krustrup et al. (2005), the average maximal heart rate during the match of elite female football players were obtained as 167 beats/min. According to the playing positions, the average maximum heart rate of female football players was 194 beats/min for goalkeepers, 183 beats/min for defenders, 181 beats/min for midfielders, and 184 beats/min for forwards. 


\section{Conclusions}

In conclusion, a 9-week training program applied during the competition period is effective on aerobic endurance level and HR recovery time in the 1st minute.

\section{Conflicts of Interest Statement}

The authors certify that there is no conflict of interest with any financial organization regarding the material discussed in the manuscript.

\section{About the Authors}

Mahmut Kurtay is a PhD student at the Department of Physical Education and Sport Education, Institute of Health Sciences, Manisa Celal Bayar University, in Manisa, Turkey. orcid.org/0000-0001-8431-5007.

Zafer Bilgin is a research assistant at the Department of Sports Health Sciences, Coaching Education Department, Faculty of Sports Science, Manisa Celal Bayar University, in Manisa, Turkey. His research interests are in fitness, crossfit, training, physical activity and health, exercise physiology, and anatomy. orcid.org/0000-0001-8464-8143.

Murat Taş is a professor at the Department of Sports Health Sciences, Coaching Education Department, Faculty of Sports Science, Manisa Celal Bayar University, Manisa, Turkey. Also, he is the dean of the Faculty of Sports Science, Manisa Celal Bayar University. His research interests are in training, physical activity and health, exercise physiology. orcid.org/0000-0003-2940-903X.

\section{References}

Açıkada C, Ergen E, 1990. Bilim ve Spor. Ankara, Tek Ofset Matbaacılık.

Açıkada C, Hazır T, Aşçı A, Turnagöl H, Aşçı A, 1999. Bir İkinci Lig Futbol Takımının Sezon Öncesi Hazırlık Döneminde Fiziksel ve Fizyolojik Profili. Futbol Bilim ve Teknolojisi Dergisi, 1999/1: 14-20.

Albinet CT, Boucard G, Bouquet CA, Audiffren M, 2010. Increased heart rate variability and executive performance after aerobic training in the elderly. European journal of applied physiology, 109(4), 617-624.

Ateş O, 2014. Soğuk iklime uyumlu sporcuların sıcak ortamda egzersize fizyolojik yanıtları. M.Ü. Sağlık Bilimleri Enstitüsü, Doktora Tezi, İstanbul.

Berntson GG, Bigger TJ, Eckberg DL, Grossman P, Kaufmann PG, Malik M, Molen VDMW, 1997. Heart rate variability: origins, methods, and interpretive caveats. Psychophysiology, 34: 623-648.

Imai K, Sato H, Hori M, Kusuoka H, Ozaki H, Yokoyama H, Takeda H, Inoue M, Kamada $\mathrm{T}, 1994$. Vagally mediated heart rate recovery after exercise is accelerated in athletes but blunted in patients with chronic heart failure. J Am Coll Cardiol. 1994; 24: 1529-1535. 
Javorka M, Zila I, Balharek T, Javorka K, 2002. Heart rate recovery after exercise: relations to heart rate variability and complexity. Brazilian Journal of Medical and Biological Research, 35(8), 991-1000.

Kizilet A, Atılan O, Erdemir I, 2010. The Effect of The Different Strength Training on Quickness and Jumping Abilities of Basketball Players Between 12 And 14 Age Group. atabesbd 2010. 12 (2): 44-57.

Krustrup P, Mohr M, Amstrup T, Rysgaard T, Johansen J, Steensberg A, Pedersen PK, Bangsbo J, 2003. The Yo-Yo Intermittent Recovery Test: Physiological Response, Reliability, and Validity. Medicine \& Science in Sports \& Exercise, 35(4), 697-705. doi: 10.1249/01.MSS.0000058441.94520.32

Krustrup P, Mohr M, Ellingsgaar H, Bangsbo J, 2005. "Physical Demands During an Elite Female Soccer Game: Importance of Training Status", Medicine Sciences Sports Exercise, 37(7), pp. 1242-1248.

Kurtay M, Turan S, Durukan E, Taş M, 2020. The Effect of Physical Performance Training on Yo-Yo İntermediate Level 1 Test Parameters in Young Soccer Players. International Journal of Sport Culture and Science. Research. Doi:10.14486/IntJSCS.2020.609

Ostojic SM, Stojanovic MD, Calleja-Gonzalez J, 2011. Ultra short-term heart rate recovery after maximal exercise: relations to aerobic power in sportsmen. Chin J Physiol, 54(2), 105-110.

Peçanha T, de Brito LC, Fecchio RY, de Sousa PN, da Silva Junior ND, de Abreu AP, da Silva GV, Mion-Junior D, Forjaz CLDM, 2016. Metaboreflex activation delays heart rate recovery after aerobic exercise in never treated hypertensive men. J Physiol 2016; 594: 6211-6223.

Rostgaard T, Iaia FM, Simonsen DS, Bangsbo J, 2008. A test to evaluate the physical impact on technical performance in soccer. Journal of Strength and Conditioning Research. doi: 10.1519/JSC.0b013e31815f302a.

Shaffer F, Gingberg JP, 2017. An Overview of Heart Rate Variability Metrics and Norms. Frontiers in Public Health.

Stolen T, Chamari K, Castagna C, Wisloff U, 2005. Physiology of soccer: An update. In Sports Medicine. doi: 10.2165/00007256-200535060-00004

Tamer K, 2000. Sporda Fiziksel Fizyolojik Perfomansın Ölçülmesi ve Değerlendirilmesi, ikinci Baskı, Ankara, Bağırgan Yayınevi; 47-131-132.

Taşkın C, Karakoç Ö, Nacaroğlu E, Budak C, 2015. Futbolcu çocuklarda seçilmiş motorik özellikler arasındaki ilişkinin incelenmesi. Spor ve Performans Araştırmaları Dergisi, 6(2): 101-107.

Yazg1 S, Y1ld1z M, 2010. Removing the effect of swallowing on the heart rate variability. 15th National Biomedical Engineering Meeting. 
Mahmut Kurtay, Zafer Bilgin, Murat Taş

COMPARISON OF THE PERFORMANCE VALUES OF THE U-16 DEVELOPMENT

LEAGUE FOOTBALL PLAYERS IN THE COMPETITION PERIOD

Creative Commons licensing terms

Authors will retain the copyright of their published articles agreeing that a Creative Commons Attribution 4.0 International License (CC BY 4.0) terms will be applied to their work. Under the terms of this license, no permission is required from the author(s) or publisher for members of the community to copy, distribute, transmit or adapt the article content, providing a proper, prominent and unambiguous attribution to the authors in a manner that makes clear that the materials are being reused under permission of a Creative Commons License. Views, opinions and conclusions expressed in this research article are views, opinions and conclusions of the author(s). Open Access Publishing Group and European Journal of Physical Education and Sport Science shall not be responsible or answerable for any loss, damage or liability caused in relation to/arising out of conflict of interests, copyright violations and inappropriate or inaccurate use of any kind content related or integrated on the research work. All the published works are meeting the Open Access Publishing requirements and can be freely accessed, shared, modified, distributed and used in educational, commercial and non-commercial purposes under a Creative Commons attribution 4.0 International License (CC BY 4.0). 